\title{
A Study on Chinese TALK Metaphor from Corpus-based Approach
}

\author{
Ruifeng Luo \\ School of English Studies, Shanghai International Studies University, Shanghai, China; \\ Foreign Language Department, Sichuan Vocational and Technical College, Suining, Sichuan, China
}

\begin{abstract}
Metaphor is a vitally important concept in Cognitive Linguistics and refers to the mapping from source domain to the target domain. It is the mapping from the concrete entity to the abstract one, through which we can understand the process of men's mental cognition to handle abstract things through specific ones and has been researching by many linguistic scholars by means of traditional methods such as introspection. The Corpus method is a newly utilized and empirical method to conduct linguistic research and contains the language materials of real and the actual use of language, and corpus is the carrier of basic language knowledge resources based on the computer. The real corpus must be processed (analysis and processing), in order to become useful resources. This paper takes advantage of CCL Corpus(Center for Chinese Linguistics Corpus) which is the biggest Chinese Corpus in China constructed by Beijing University to investigate TAKL metaphor and conduct the empirical research to make metaphor research more objective and convincing.
\end{abstract}

Index Terms-metaphor, corpus, TALK, CCL

\section{INTRODUCTION}

Metaphor is sometimes and traditionally used as a general term for figurative or non-literal language. It is difficult to determine whether a word or phrase should be understood metaphorically or not. In Cognitive Linguistic view, metaphor is a creative process in which an existing linguistic form is used to express a meaning similar, but not identical, to its conventional meaning (Kovesces 2002). Individual metaphors are built on an inferable analogy between the original and the novel meanings, or the 'source' and 'target' meanings in Lakoff and Johnson (1980)'s terms. Importantly, however, metaphor is not a deviant special case of language use, nor is literal use the default setting for language; Metaphorical language use is often speciously considered exceptional only because of the seductively erroneous assumption that language is a tool which enables the speaker to encode meaning and the hearer to decode it (Wilson \& Sperber 2012). Linguistic communication is, however, not simply an encoding-decoding process, nor is it even a process of reverse-engineering in which the hearer puts the speaker's original meaning back together again (Mufwene 2002; Brighton, Smith, \& Kirby 2005). Rather it is best characterised by the complementary processes of ostension and inference (Sperber \& Wilson 1995). Metaphors are defined by the analogical connections which can be drawn between the source and target meaning, and are interpreted in the same way: the hearer infers the parts of the source meaning relevant in the communicative context and constructs an ad-hoc interpretation based on the relevant semantic fragments.

Corpus contains a large scale computer-aided analysis of very extensive collections of transcribed utterances or written texts. Corpus data has led to methodological and theoretical innovation in linguistics in general. Clear and detailed explanations lay out the key issues of method and theory in contemporary corpus linguistics. A structured and coherent narrative links the historical devel-opment of the field to current topics in 'mainstream' linguistics. Practical activities and questions for discussion at the end of each chapter encourage students to test their understanding of what they have read and an extensive glossary provides easy access to definitions of all technical terms used in the text (McEnery \& Hardie 2012). Currently, the research of Metaphor of Cognitive Linguistics is more convincing with the benefit from the empirical support provided by Corpus data.

Language is the most important communication tool for human beings. As a medium for human communication, language has an impact on politics, economy and society, science and technology, and culture. The cultural phenomenon of language is developing constantly, and its present spatial distribution is also the result of the development of the past. People use language to preserve and transmit the fruits of human civilization. Language is one of the most important characteristics of a nation. Talking is the oral manifestation of human communication, and we do a lot of talking every day to communicate with others. TALK is the most direct way for people to express themselves and transmit information. Thanks to talking, the relationship between people begins to become tight.

\section{METHODS}

As TALK can express people's thoughts and feelings, it has its own abstract features. However, in the use of language, people give it physical features by means of metaphor. In the contemporary view of metaphor, metaphor is not only a rhetorical phenomenon but a way of perceiving the world by human beings, in which human beings utilize the 
experiences of one domain to explain or understand concepts of other domains. Metaphor is pervasive in human life. The TALK itself is just a voice form (spoken language) or text symbols (written) and the semantic carrier, which is abstract. But when people take as TALK as object, they often use the metaphor way to use the attribute of other things to understand it. The "talking", is abstract and difficult to understand. In order to enable people to understand this communication tool, this paper will study how the TALK's source domains are mapped onto its target domain with the help of the data attracted from CCL Corpus. The key word TALK related Chinese words such as hua 话, yan 言, shuohuaxiang 说话像, shuohuaru 说话如 are examined on CCL Corpus to get the sentences containing above words. If the numbers of the sentences are many that 2000 sentences are selected. And, the sentences of TALK which are met the standard of metaphor are selected from which the percentage is drawn to show the distribution of metaphor in the chosen sentences.

TABLE1.

TALK METAPHOR IN CCL

\begin{tabular}{lllll}
\hline Lexical items & English Translation & Total Numbers & Numbers of Metaphor & Percentage \\
\hline hua 话 & Talk & 2000 & 67 & $3.35 \%$ \\
\hline yan 言 & Talk & 2000 & 31 & $1.55 \%$ \\
\hline shuohuaxiang 说话像 & “Talk” is like & 45 & 18 & $40 \%$ \\
\hline shuohuaru 说话如 & “Talk” is like & 15 & 13 & $86.66 \%$ \\
\hline
\end{tabular}

Table1 shows that life is the target domain and English TALK has two Chinese translations, namely, hua 话 ( shuohua 说话) and yan 言. We use the Chinese lexical items hua 话 (shuohua 说话) “Talk”, yan 言“Talk”, shuohuaxiang 说话 像 “Talk is like”, shuohuaru 说话如 “Talk is like” retrieve them in CCL respectively to see how many metaphors there are in their respective total numbers and what are their source domains.

In hua 话 (shuohua 说话) “Talk”,the total surveyed numbers of sentences containing hua 话 (shuohua 说话) “Talk” are 2000, and the numbers of metaphor are 67. The percentage of metaphors is $3.35 \%$. The hua 话 (shuohua 说话) “Talk” relevant metaphors are paochuyijuhua 抛出一句话 “throw a word”, hualoudongbaichu 话漏洞百出 “The loopholes appeared in the words one after another.”, huasuanliuliu 话酸溜溜 “The word is sour.”, zhonghua 重话 “heavy words”, huaxiazi 话匣子 “talking box”, huashuodedishuibulou 话说得滴水不漏 “speak words tightly”, qinghua 情话“affectionate words”, ruanhua 软话 “soft words”, yinghua 硬话 “hard words”, changhuaduanshuo 长话 短说 “cut a long word short”, huafeng 话锋 “topic of conversation”, huatou 话头 "the beginning of the words", huabing 话柄“handle”, hualiyouci 话里有刺 “words with sting”, wenluandehuayu 温暖的话语 “warm words”, huabingbingliang 冷冰冰的话 “cold words”, huahuoyaoweihennong 话火药味很浓 “the words are full of the smell of gunpowder", etc.

In yan 言“Talk", the total surveyed numbers of sentences containing yan 言 “Talk” are 2000, and the numbers of metaphor are 31. The percentage of metaphors is $1.55 \%$. yan 言 “Talk” relevant metaphors are zhiyanpianyu 只言片语 “isolated words”, yanfangxingyuan 言方行圆 “contradictions between words and deeds”, yanzhiwuwen 言之无文 “words without literary”, yanquan 言泉 “words as spring water gushed out”, yanbujinyi 言不尽意“Words cannot express all one intends to say”, yantongleshi 言同勒石 “profound and precious words”, qingyanxiyu 轻言细语 “mild tone”, renweiyanqing 人微言轻 “one's word does not carry much weight.”, yanzhong 言重 “heavy words”, jinshiliangyan 金石良言 “good advice”,tianyanmiyu 甜言蜜语 “honeyed words”, kuyanxiangquan 苦言相劝 "persuade with honest words".

In shuohuaxiang 说话像 "Talk" is like", the total surveyed numbers of sentences containing shuohuaxiang 说话像 "Talk" is like" are 45, and the numbers of metaphor are 18. The percentage of metaphors is 40\%. The shuohuaxiang 说 话像 “Talk is like” relevant metaphors are shuohuaxiangdayami 说话像打哑谜一样 “Talk”is like guessing”, shuohuaxiangfanglianzhupao 说话像放连珠炮 “Talk”is like guessing”, shuohuaxiangchaodouzi 说话像炒豆子“Talk is like fried beans", shuohuaxiangjisuanjiyiyangkuaisuheqingxi 说话像计算机一样快速和清晰 “Talk is like a computer quickly and clearly”, shuohuaxiangjiyagaoyiyang 说话像挤牙膏一样 “Talk is like squeezing toothpaste”, shuohuaxiangheshuihuanhuanliudong 说话像河水缓缓流动 “Talk is like a river flowing slowly”, shuohuaxiangfangpaozhang 说话像放炮仗 “Talk is like firecracker”, shuohuaxiang yinhangzhangmuyiyangzhenmi 说 话像银行帐目一样缜密 “Talk is like meticulous bank accoun”, shuohuaxiangkaijiguanqiang 说话像开机关枪 “Talk is like a machine gun”, shuohuaxiangchileqiangzi 说话像吃了枪子 “Talk is like eating bullets”, shuohuaxiangqiaozhong 说话像敲钟 “Talk is like a bell”, shuohuaxiangyizhilijian 说话像一支利箭 “Talk is like a sharp arrow”, shuohuaxiangyanzi 说话像燕子 “Talk is like a swallow”, shuohuaxiangniaoyujijizhazha 说话像鸟语吹 吹喳喳 “Talk is like birds chirping”, shuohuaxiangguafengside 说话像刮风似的 “Talk is like the wind blowing”, shuohuaxiangchangge 说话像唱歌 “Talk is like singing”, etc.

In shuohuaru 说话如 “Talk” is like”, the total surveyed numbers of sentences containing shuohuaru 说话如 “Talk is like" are 15 , and the numbers of metaphor are 13 . The percentage of metaphors is $86.66 \%$. shuohuaru 说话如 “Talk is 
like” relevant metaphors are shuohuarutongerxi“说话如同儿戏“Talk” is like a trifling matter.”, shuohuarutongshengzhi 说话如同圣旨 “Talk is like a decree.”, shuohuarutongdadianhuayiyangqingxi 说话如同打电话一样清晰 “Talk is like clear calling.”, shuohuarutongfangpi 说话如同放屁“Talk is like fart.”, shuohuarutongbairanzao 说话同白染皇 “Talk is like soap dye.",etc.

From the table1,we can see that the numbers of metaphor of shuohuaru 说话如 “Talk is like" and shuohuaxiang 说 话像 “Talk is like” are highest accounting for $86.66 \%$ and $40 \%$ respectively. The numbers of metaphor of hua 话、yan 言“Talk are lowest accounting for $3.35 \%$ and $1.55 \%$ respectively.

\section{RESULTS AND EXPLANATIONS}

According to the examples from CCL, we can conclude that TALK metaphors fall into different source domain: Material domain, State Domain, Sensory Domain.

\section{A. Material Domain}

Chinese always metaphorizes "words" as a container which can hold things, such as, hualiyouhua 话里有话 "have one's tongue in one's cheek", huaxiaozi 话匣子 “talking box”, etc.

There are internal and external sides in the container. So there is the expression of "the word outside" and "the word inside" in Chinese, and words as a container can not only store things, but also can be opened and closed. As the material, words have two types: soft words and hard words.

(1) 他误认为我话里有话, 眼睛中的灰色变得湛蓝。我看着他年轻起来的脸, 皱纹和白发都成了一种伪装。

$\begin{array}{lllllll}\text { Ta } & \text { wurenwei } & \text { wo } & \text { hua } & \text { li } & \text { you } & \text { hua, } \\ \text { M,3SG } & \text { misunderstand } & \text { 1SG } & \text { wordPL } & \text { inLOC } & \text { have } \\ \text { yanjing } & \text { zhong } & \text { de } & \text { huise } & \text { biande } & \text { zhanlan. } & \text { wo } \\ \text { eye } & \text { inLOC } & \text { POSS } & \text { grey } & \text { become } & \text { blue. } & \text { 1SG } \\ \text { kanzhe } & \text { ta } & \text { nianqing } & \text { qilai } & \text { de } & \text { lian, } & \text { zhouwen } \\ \text { look } & \text { M,3SG } & \text { young } & \text { up } & \text { POSS } & \text { face, } \\ \text { he } & \text { baifa } & \text { chengle } & \text { yizhong } & \text { weizhuang. } & & \text { wrinkle } \\ \text { and } & \text { white hair } & \text { become } & \text { CLF } & \text { camouflage. } & \end{array}$

He misunderstood that I had my tongue in my cheek and his eyes became grey blue. I looked at his young face, wrinkles and white hair had become a camouflage.

Words as container can also store things, feelings and emotions.

(2) 他对那个孤儿说的话饱含深情。

$\begin{array}{lllllll}\text { Ta } & \text { dui } & \text { nage } & \text { gu'er } & \text { de } & \text { hua } & \text { baohan } \\ \text { M,3SG } & \text { DAT } & \text { that } & \text { orphan } & \text { POSS } & \text { words } & \text { full } \\ \text { shenqing. } & & & & & \\ \text { affection. } & & & & & \end{array}$

The words he said to the orphan was full of affection.

(3) 这篇散文言辞优美, 诗意盎然。

\begin{tabular}{|c|c|c|c|}
\hline $\begin{array}{l}\text { Zhepian } \\
\text { CLF }\end{array}$ & $\begin{array}{l}\text { sanwen } \\
\text { prose }\end{array}$ & $\begin{array}{l}\text { yanci } \\
\text { words }\end{array}$ & $\begin{array}{l}\text { youmei, } \\
\text { refined }\end{array}$ \\
\hline
\end{tabular}

The prose has refined words and is poetic.

(4) 既然大家把话说开了, 那也没事了, 咱们还是抓紧进行会议的下一议程吧。

$\begin{array}{lllllll}\text { Jiran } & \text { dajia } & \text { ba } & \text { hua } & \text { shuo } & \text { kai le, } & \text { na } \\ \text { As } & \text { 3PL } & \text { CAUS } & \text { words } & \text { talk } & \text { open, } & \text { then } \\ \text { yemei } & \text { shi le, } & \text { zamen } & \text { haishi } & \text { zhuajin } & \text { jinxing } & \text { huiyi } \\ \text { NEG } & \text { problem, } & \text { 1PL } & \text { still } & \text { hurry } & \text { doPROG } & \text { meeting } \\ \text { de } & \text { xiayi } & \text { yicheng } & \text { Ba! } & & & \\ \text { POSS } & \text { next } & \text { agenda } & \text { IMP } & & & \end{array}$

Now that we have talked things out, it is all right. Let's hurry up to the next agenda of the meeting.

(5) 几杯酒下肚后, 小伙子打开了话匣子。

$\begin{array}{lllllll}\text { Ji } & \text { bei } & \text { jiu } & \text { xia } & \text { du } & \text { hou, } & \text { xia } \\ \text { CLF } & \text { cupPL } & \text { wine } & \text { down } & \text { stomach } & \text { after, } & \text { young } \\ \text { huozi } & \text { dakai le } & \text { hua } & \text { xiazi. } & & & \\ \text { fellow } & \text { openPST } & \text { talk } & \text { box. } & & & \end{array}$

After a few drinks, the guy opened the talkingbox.

(6) 他知道妻子心肠软, 就一个劲儿地说软话。 


$\begin{array}{lllllll}\text { Ta } & \text { zhidao } & \text { qizi } & \text { xinchang } & \text { ruan, } & \text { jiu } & \text { yige jing de } \\ \text { M,3SG } & \text { know } & \text { wife } & \text { heart } & \text { kind, } & \text { then } & \text { constantADV } \\ \text { shuo } & \text { ruan } & \text { hua. } & & & & \\ \text { say } & \text { soft } & \text { words. } & & & \end{array}$

He knew his wife was soft, and he said soft words to her.

（7）新中国建立初期我中国怎敢谈那类强硬话呢?

$\begin{array}{lllllll}\text { Xin } & \text { zhongguo } & \text { jianli } & \text { chu } & \text { qi } & \text { wo zhongguo } & \text { zem } \\ \text { New } & \text { China } & \text { foundPASS } & \text { beginning } & \text { period } & \text { 1PM } & \text { NEG AUX } \\ \text { gan } & \text { tan } & \text { nalei } & \text { qiangying } & \text { hua } & \text { Ne? } & \\ \text { dare } & \text { say } & \text { such } & \text { hard } & \text { words } & \text { Q } & \end{array}$

How can China dare to say such hard words in the founding of People' Republic of China?

\section{B. State Domain}

We humans live in the physical world, and know things from the understanding of the specific matter, which provides the material basis for our physical experience to understand and express thoughts and feelings and psychological abstract fuzzy activities, events, and other intangible concepts. In general, we tend to organize our non-physical experiences with physical experiences. The expression and understanding of words are abstract, and people always use the metaphorical cognitive approach to make the TALKmetaphor a concrete and tangible entity.

Words has the feature of Weight.Because the object has a weight, "words", after being metaphorized into entity, has the weight difference.The weight difference depends on the importance of "words" in the minds of people.In general, important words" shows the feature of weigh and vice versa.

Words has the feature of shape. As an object, it has an external shape. When we make the words metaphor into an entity, we also give the words a certain shape.

(8) 她举止优雅,说话轻言细语,一副江南女子的模样。

\begin{tabular}{|c|c|c|c|c|c|c|}
\hline $\begin{array}{l}\text { Ta } \\
\text { F,3SG } \\
\text { nvzi } \\
\text { woman }\end{array}$ & $\begin{array}{l}\text { juzhi } \\
\text { manner } \\
\text { de } \\
\text { POSS }\end{array}$ & $\begin{array}{l}\text { youya, } \\
\text { Elegant, } \\
\text { moyang. } \\
\text { image. }\end{array}$ & $\begin{array}{l}\text { shuohua } \\
\text { talk }\end{array}$ & $\begin{array}{l}\text { qingyan xiyu, } \\
\text { gentleADV }\end{array}$ & $\begin{array}{l}\text { yifu } \\
\text { CLF }\end{array}$ & $\begin{array}{l}\text { jiangnan } \\
\text { South of China }\end{array}$ \\
\hline
\end{tabular}

She is elegant talks gentlely and is a typical Jiangnan woman.

(9) 你可以觉得自己是人微言轻的无名之辈, 也可以心灵充实。

$\begin{array}{lllllll}\mathrm{Ni} & \text { keyi } & \text { juede } & \text { ziji } & \text { shi } & \text { renwei yanqin } & \text { de } \\ 2 \mathrm{SG} & \text { AUX } & \text { think } & \text { REFL } & \text { COP } & \text { humble } & \text { POSS } \\ \text { wuming zhi bei, } & \text { ye } & \text { keyi } & \text { xinling } & \text { chongshi. } & & \\ \text { nobody, } & \text { also } & \text { AUX } & \text { heart } & \text { enrich. } & & \end{array}$

Though you think you are in humble position and your word does not carry weight,you can also enrich your heart.

(10) 听了孙中山这一番语重心长的话语后, 当时几个孩子深受鼓舞, 且仿佛一下长大了许多似的。

$\begin{array}{llllll}\text { Ting le } & \text { Sunzhongshan } & \text { zheyi fan } & \text { yuzhongxinchang } & \text { de } & \text { hosS } \\ \text { ListenPST to } & \text { Sunzhongshan } & \text { CLF } & \text { sincere } & \text { guwu, } & \text { words after, } \\ \text { dangshi } & \text { jige } & \text { haizi } & \text { shenshou } & \text { inspirePASS, } \\ \text { ADV } & \text { CLF } & \text { children } & \text { deepADV } & & \text { fangfu } \\ \text { yixia } & \text { zhangda le } & \text { xuduo } & \text { si de. } & \\ \text { suddenly } & \text { growPERF } & \text { a lot } & \text { DUR. } & \end{array}$

After hearing Sun Zhongshan's sincere words,the children were inspired, and seemed to grow a lot.

(11) 老师的话很有分量, 学生们只有乘乘服从。

$\begin{array}{lllllll}\text { Laoshi } & \text { de } & \text { hua } & \text { hen } & \text { you } & \text { fenliang, } & \text { xuesheng men } \\ \text { teacher } & \text { POSS } & \text { words } & \text { ADV } & \text { have } & \text { weight, } & \text { studentPL } \\ \text { zhi you } & \text { guaiguai } & \text { fucong. } & & & & \\ \text { only } & \text { obedient } & \text { obey. } & & & & \end{array}$

The teacher's words carries weight and the students only obediently obey.

(12) 老师对学生的失败说了一句轻飘飘的话。

$\begin{array}{lllllll}\text { Laoshi } & \text { dui } & \text { xuesheng } & \text { de } & \text { shibai } & \text { shuo le } & \text { yiju } \\ \text { teacher } & \text { DAT } & \text { studentPL } & \text { POSS } & \text { failure } & \text { sayPST } & \text { CLF } \\ \text { qing piaopiao } & \text { de } & \text { hua. } & & & & \\ \text { light } & \text { POSS } & \text { words. } & & & & \end{array}$

The teacher said a light words to the students who failed in the examinations. 
(13) 中国队也要用实力来赢球, 不要给别人话柄。

$\begin{array}{lllllll}\text { Zhongguo } & \text { dui } & \text { ye yao } & \text { yong } & \text { shili lai } & \text { ying } & \text { qiu, } \\ \text { Chinese } & \text { team } & \text { also FUT } & \text { use } & \text { strength } & \text { win } & \text { game, } \\ \text { buyao } & \text { gei } & \text { bieren } & \text { huabing. } & & & \\ \text { NEG } & \text { DAT } & \text { otherPL } & \text { handle. } & & \end{array}$

Chinese team should use its strength to win the game, don't give others handle.

(14) 一位老大爷慢悠悠地接过话茬儿。

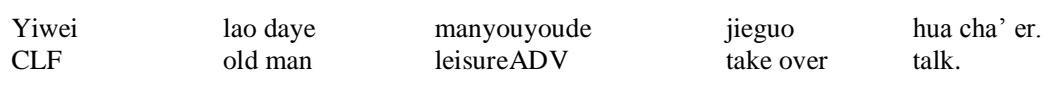

An old man leisurely talked with others.

(15) 见他收不住话头, 妻子忙给他使眼色, 并卙满酒向着客人唱起了欢乐的歌。

$\begin{array}{lllllll}\text { Jian } & \text { ta } & \text { shou } & \text { buzhu } & \text { hua tou, } & \text { qizi } & \text { mang } \\ \text { Look at } & \text { M,3SG } & \text { stop } & \text { NEG AUX } & \text { words } & \text { wife } & \text { busy } \\ \text { gei } & \text { ta } & \text { shi } & \text { yanse, } & \text { bing } & \text { zhenman } & \text { jiu } \\ \text { DAT } & \text { M,3SG } & \text { give } & \text { Wink, } & \text { and } & \text { fill } & \text { wine } \\ \text { xiangzhe } & \text { keren } & \text { chang qi le } & \text { huanle de } & \text { ge. } & & \\ \text { DAT } & \text { guestPL } & \text { sing } & \text { jouful } & \text { song. } & \end{array}$

He could not stop his words and the wife was busy giving him a wink and filled wine to the guests to sing the song.

\section{Sensory Domain}

Words are heard by people with ears and then people use the brain to understand its meaning. Different words causes different feelings in the minds of different people,so different words are then metaphorized into different things and different things give people various feelings. And some feelings have similarities though they are diverse. So through the feeling transfer,we get the words with characteristics which are sour, sweet, bitter, hot and cold,pain.

(16) 我的意见完全是被杨某的甜言蜜语所欺骗。

$\begin{array}{lllllll}\text { Wo } & \text { de } & \text { yijian } & \text { wanquan } & \text { bei } & \text { yang mou } & \text { de } \\ 1 \text { SG } & \text { POSS } & \text { opinion } & \text { completeADV } & \text { PASS } & \text { yang } \\ \text { tianyanmiyu } & \text { suo } & \text { qipian. } & & & \text { POSS } \\ \text { sweet words } & \text { PASS } & \text { fool. } & & & \end{array}$

My opinion is completely fooled by Yang's sweet words.

(17) 医院明白了张朝安为什么要提出带张春华回乡, 更加苦言相劝。

$\begin{array}{lllll}\text { Yiyuan } & \text { mingbai le } & \text { zhangchaoan } & \text { weishenme } & \text { yao } \\ \text { Hospital } & \text { understand } & \text { zhangchaoan } & \text { why } & \text { have } \\ \text { dai } & \text { zhangchunhua } & \text { huixiang, } & \text { gengjia } & \text { kuyuan } \\ \text { take } & \text { zhangchunhua } & \text { back home, } & \text { COMPA } & \text { honestwords }\end{array}$

The hospital understood why Zhang Chao'an wanted to take Zhang Chunhua home, and persaded him honestly.

(18) 别老说那些酸溜溜的话。

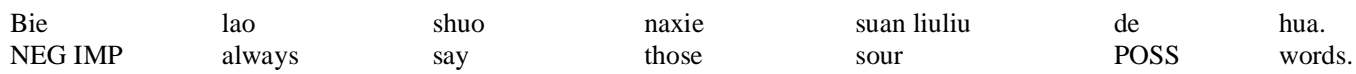

Don't say those sour words again and again.

(19) 看到一张张亲切的脸, 听到那一声声温暖的话语, 我便激动不已。

$\begin{array}{lllllll}\text { Kandao } & \text { yi zhangzhang } & \text { qinqie } & \text { de } & \text { lian, } & \text { ting dao } & \text { na } \\ \text { See } & \text { CLF } & \text { kind } & \text { POSS } & \text { facePL, } & \text { hear } & \text { that } \\ \text { yishengsheng } & \text { wenluan } & \text { de } & \text { huayu, } & \text { wo } & \text { bian } & \text { jidong } \\ \text { CLF } & \text { warm } & \text { POSS } & \text { words, } & \text { 1SG } & \text { then } & \text { exciteADJ }\end{array}$

Seeing the kind faces and hearing the sound of warm words, I felt excited.

(20) 电话那头甩来一位女士生硬冰冷的话,便挂断了。

$\begin{array}{llllll}\text { Dianhua } & \text { natou } & \text { shuailai } & \text { yiwei } & \text { nvshi } & \text { shengying bingleng } \\ \text { Phone } & \text { opposit side } & \text { transfer } & \text { CLF } & \text { lady } & \text { stiff } \\ \text { de } & \text { hua, } & \text { bian } & \text { guaduan le. } & & \\ \text { POSS } & \text { words, } & \text { then } & \text { hung up. } & & \end{array}$


Upon hearing a lady' stiff and cold words from the phone, I found the phone hung up.

\section{CONCLUSION}

This paper makes a tentative analysis of the metaphorical meaning of "words" by means of corpus and cognitive linguistics to show that TALK is abstract but by means of metaphor, we can use the concrete entities to describe it and make it tangible and easy to understand. The Corpus data offers valid and real language materials to explain the amount of metaphor TALK in real world. We can see that the understanding of the concept TALK depends on the other related concepts such as material, food, taste, etc. These materials are closely related to our daily lives and provides vivid picture to let the men know how concrete our TAKL metaphor is because we know these experiences well. So metaphor is grounded in our daily experiences. All the understanding of TALK must be connected with these concepts by means of metaphor. It is difficult to talk about the concept of TALK without these elements in source domains. The reason why life is so rich in metaphorical expression is that metaphor mapping is a process of feature focus and feature suppression. Every focus of the metaphor of talk can only highlight the characteristics of a certain aspect, and all aspects of TALK need to be understood.

\section{ACKNOWLEDGEMENTS}

This research was financially supported by the Fund Project of Education Department of Sichuan Province. (The Application of Dynamic System Theory in English and Chinese Attrition, NO. 16SB0293)

\section{REFERENCES}

[1] Brighton, H, K. Smith \& S. Kirby. (2005). Language as an evolutionary system. Physics of Life Reviews 2 (3). 177-226.

[2] He Jianyou. (2013). An analysis of the metaphorical meaning of "the word" from the perspective of cognition. Journal of Huaibei Normal University (Philosophy and Social Sciences Edition) (5). 107-110.

[3] Kovesces, Zoltan. (2002). Metaphor: A practical introduction. Oxford: Oxford University Press.

[4] Lakoff, G. \& Johnson, M. (1980). Metaphors We Live By. Chicago: The University of Chicago Press.

[5] LiWenli. (2004). Metaphorical cognitive model of "words". Journal of Fuin Normal College (7). 48-50.

[6] Mufwene, S. S. (2002). Competition and selection in language evolution. Selection 3 (1). 45-46.

[7] Mc Enery \& Hardie. (2012). Corpus linguistics. Cambridge: Cambridge University Press

[8] Wilson, D\& D. Sperber. (2012). Meaning and relevance. Cambridge: Cambridge University Press

Ruifeng Luo was born in Sichuan, China in 1982. He is studying for doctorate of Linguistics in School of English Studies of Shanghai International Studies University, China.

He is currently a lecturer in the Department of Foreign Languages, Sichuan Vocational and Technical College, SuiNing, China. His research interests include Cognitive Linguistics and Functional Linguistics. 